\title{
THE POLYMORPHISM IN THE DYSTROPHIN GENE (DMD) OF VARIOUS BREEDS OF THE PIGS IN THE BELGOROD REGION OF RUSSIA
}

\author{
Anton A. Sychev ${ }^{1 *}$, Eduard A. Snegin ${ }^{1}$, Olesia Yu. Artemchuk ${ }^{1}$, Anatolii S. Barkhatov ${ }^{1}$, \\ Sergei R. Yusupov ${ }^{1}$, Elena A. Snegina ${ }^{1}$, Aleksandra Yu. Tishchenko ${ }^{1}$ \\ 1*Belgorod State University, Pobedy Str., 85, Belgorod, 308015, Russia. \\ *Corresponding Author Anton A. Sychev, e-mail: sychev@bsu.edu.ru;
}

Received August 2021; Accepted September 2021; Published October 2021;

DOI: $\underline{\text { https://doi.org/10.31407/ijees11.449 }}$

\begin{abstract}
The pigs were genotyped for the dystrophin gene (DMD) using the ACRS-PCR method. The study examined 215 boars of four breeds (Duroc, Large White, Landrace and Yorkshire) from the Belgorod region of Russia. The mutation in the DMD gene leads to dystrophin expression decrease in the muscles of the lumbar region, longissimus dorsi, and also in the diaphragm. The animals with the mutant allele $\mathrm{T}$ had the average daily gain decrease in live weight, the fat thickness of the muscle layer depth reduction. To assess the frequency of alleles and genotype occurrence for the DMD gene among the Landrace, Duroc, Large White and Yorkshire breeds that are bred on the farms of the Belgorod region of Russia. Genomic DNA was isolated from alcoholized earmarks. Pig genotyping was performed using ACRS-PCR (Amplification Created Restriction Sites). Using primers, 151 b.p. DNA fragment was amplified from the forty-first exon of the dystrophin gene containing the target mutation. Primers were designed using the Primer3 software. $10 \mu \mathrm{l}$ of the PCR product were hydrolyzed with 4 units of the Mox20I restriction enzyme (SibEnzyme, Russia) for 16 hours. The hydrolysis products were separated by horizontal electrophoresis in $4 \%$ agarose gel. Then, based on the results obtained, the pigs were genotyped by TaqMan PCR.The mutant allele T is observed only in the Landrace livestock with the frequency of 0.405 . This is significantly higher than in the livestock of this breed from other regions and can be caused by the peculiarities of local selection. Based on the verified genotypes, they developed the method of pig genotyping for the DMD gene using real-time PCR technology based on TaqMan fluorescent probes. The high efficiency and reliability of the results of the TaqMan PCR technique and the possibility of its use in routine practice have been shown. The methods of pig genotyping for DMD gene mutations have been developed using ACRS-PCR and real-time PCR using TaqMan technology. The analysis of allele frequencies and genotypes of boars from the Duroc, Large White, Landrace and Yorkshire breeds at the farms of the Belgorod region of Russia was carried out according to the polymorphism of the dystrophin gene. As compared to previously obtained data from other regions of Russia, higher frequencies of the mutant allele $\mathrm{T}$ were revealed for the Landrace breed, which may be associated with the peculiarities of local selection for productive traits.
\end{abstract}

Key words: pigs, dystrophin gene, ACRS-PCR, TaqMan PCR 